\title{
Law Protection on Wife Whose The Claims Fall Due To Husband Refuse His Recompensation On Implementing Of Divorce Pledge
}

\author{
Farhan Munirus Su'aidi ${ }^{1}$ and Abdullah Arief Cholil ${ }^{2}$
}

Abstract. Decision granting a divorce pledge would fall if the husband was reluctant oath within six (6) months from the date of the hearing determination pledge. The fall verdict carries legal consequences fall anyway recompensation lawsuit filed by the wife. This study aimed to analyze the norms of protection of women and seek forms of law protection that can be given by the Court on the lawsuit wife his recompensation fall due reluctant husband dropped the divorce pledge.

This type of research is normative by using the approach of law (statute approach) and conceptual (conceptual approach), using primary legal materials in the form of norms related to the protection of women and secondary legal materials such as the results of previous studies as well as data obtained through interviews is analyzed with the theory of protection and legal certainty as well as apply the legal principle Similia Similibus and Res Judicata Pro Veritate Habeturand the principle is simple, fast and low cost in the hope of giving recommendations that can be implemented to address the issues of law covered in the study.

The results showed no norms whose provide law protection to wives whose husbands due to the fall lawsuit his recompensation pledge reluctantly dropped the divorce. The court can give law protection in the form of provision of facilities in the areas of administration and law of procedure for the wife who would resubmit its case in accordance with the legal principle is simple, fast and low cost.

Keywords: Law Protection; Wife; Recompensation Lawsuit, Fall; Divorce Pledge.

\section{Introduction}

The granting of the divorce pledge is accompanied by the imposition of obligation towards her husband through decisions that have permanent legal force would be void if the husband is not in divorce pledge within six (6) months from the decision of the Court of Religion on permit divorce pledge her and bond his marriage remain intact. Such provisions can be found in the provisions of Article 70 paragraph (6) of Act No. 7 of 1989 On the Religious Courts as amended by Act No. 3 of 2006 and the second amendment to Act No. 50 of 2009 in conjunction with Article 131 paragraph (4) Compilation of Islamic Law.

The legal consequences of divorce verdict fall divorce is marriage bond between husband and wife is still intact despite the fact that the relationship between husband and wife is not good, can not be united again and the marriage bond can not be maintained as much thinking in granting permission to divorce pledge.

\footnotetext{
${ }^{1}$ Student of Master of Law, Universitas Islam Sultan Agung Semarang and Religious Court Judge of Blora, email: farhan30972@yahoo.co.id

${ }^{2}$ Lecturer of Master of Law, Sultan Agung Islamic University (UNISSULA), Semarang
} 
The strength of the verdict whose then fall impact or due to tort law wife recompensation whose has been granted by the judges be killed anyway, the decision to be non executable recompensation lawsuit or unenforceable. Wife struggle to defend their rights after a lengthy trial process becomes useless due to fall due to the reluctance husband's decision to implement a divorce pledge. The not good desire from the husband obviously would cause harm to the wife.

In practice, if the wife feels aggrieved by the decision of divorce who died as a result of the husband was reluctant oath of divorce, to defend their rights back then he would file a legal action to file for divorce just accompanied acumulation of a lawsuit as it has been filed in the lawsuit recompensation and the trial will starting again from scratch. Based on the description above, this study will answer the formulation of the following problems:

- Is there a norm that is sufficient to provide protection to wives whose husbands lawsuit his recompensation fall due to divorce pledge?

- What form of law protection that can be given by the Court on wife of the lawsuit whose husband reluctant his recompensation fall due to divorce pledge?

\section{Research methods}

Specifications research is normative, ie legal research done by researching library materials or secondary data, ${ }^{3}$ sourced from primary legal materials include legislation and jurisprudence as well as secondary law covering the results of previous studies as well as interviews with the wife of a lawsuit his recompensation fall due reluctant husband dropped the divorce.

The approach used is a law (statute approach) is used to examine and review the regulations related to the main theme of research and conceptual approach depart from the prevailing doctrine or viewpoint ${ }^{4}$ so found the ideas that gave birth to the concept or idea that can be implemented in law enforcement oriented rights protection law wife.

Mechanical collection of legal materials is done by an inventory of legislation, jurisprudence, books, journals, and scientific publications relevant to the theme of research and interviews with the wife of a lawsuit his recompensation fall. Overall legal materials obtained are then analyzed by using the theory of law protection and legal certainty as well as applying the legal principle of Similia Similibus and Res Judicata Pro Veritate Habeturand the principle is simple, fast and low cost of the estuary will produce research that is prescriptive by giving recommendations to address the problem law discussed in this study.

\section{Results and Discussion}

\footnotetext{
${ }^{3}$ Soerjono Soekanto and Sri Mamuji, Penelitian Hukum Normatif Suatu Tinjauan Singkat, Raja Grafindo Persada, Jakarta, 2010, p. 13-14.

4Johnny Ibrahim, Teori \& Metodologi Penelitian Hukum Normatif, Bayu Media Publishing, Malang, 2008, p. 300.
} 


\subsection{Norms Related on Law protection for Women}

Material laws that made the object of research is the legislation that has to do with the status and rights of citizens before the law and the protection given by the government, especially against women in conflict with the law, namely:

- 1945 opening

In the fourth paragraph of the Preamble of the Constitution of 1945 in mind one purpose of establishing the State of Indonesia is to protect the entire Indonesian nation and the country of Indonesia. One of the basic norms contained in the Preamble to the Constitution paragraph fourth is the state in this case the government has an obligation to protect all Indonesian citizens without exception, there is no difference between citizens is well different ethnic, religion, skin color and gender differences, so protection law is basic rights all citizens Indonesia is the duty of the government to implement them.

- Constitution of the Republic of Indonesia 1945.

Article 27 paragraph (1), Article 28D (1) and Article 28H paragraph (2) is more specific to the protection of citizens in the legal field. The provisions of these norms basically stated that all citizens have equal standing before the law, have the same rights guaranteed by law, law protection and obtain legal certainty. Article $28 \mathrm{H}$ paragraph (2) already alluded to the right to get the ease and special treatment in order to obtain equality before the law and justice are the same. The provisions of this article can be used as a basis to create special rules that provide protection to citizens who are legally in the position of the weak and marginalized.

- Act No. 1 Of 1974 On Marriage

The provisions stipulated in Act No. 1 Of 1975, Article 41 letter c has authorized the court through judge to give protection to the ex-wife divorced. Rights owned ex officio judge because of his position with the aim to protect the rights of ex-wife during a divorce, although the wife of the trial not to press charges.

The norms in the article are already more specifically provide protection to the wife to be divorced from her husband, but the wife tort cases whose fall due reluctant husband dropped the divorce has not been accommodated in the provision.

- Government Regulation No. 9 of 1975 On Implementation of Act No. 1 of 1974 On Marriage

Article 24 paragraph (1) authorizes the Court by the judge during the proceedings, anticipating the danger whose may arise, could impose a preliminary injunction or judgment by injunction requested by the parties.

Article 24 paragraph (2) in accordance with the provisions stipulated in Act No. 1 Of 1975, Article $41 \mathrm{c}$, whose gives hak ex officio to the judge because of his position with the aim to protect the rights of ex-wife during a divorce.

- Law of the Republic of Indonesia Number 7 of 1984 concerning the Ratification of Convention on the Elimination of All Forms of Discrimination against Women (Convention On The Elimination Of All Forms Of Discrimination Against Women). 
Article 15 of Act No. 7 of 1984 obliges participating countries to ensure equality of rights between men and women before the law. Given the same rights in civil affairs in the fields of civil, equal rights at all levels in conflict with the law.

Article 16 of Act No. 7 of 1984 are more firm requires participating countries to make regulations that provide protection to women in matters relating to marriage.

- Act No. 7 of 1989 On the Religious Courts as amended by Act No. 3 of 2006 and the second amendment to Act No. 50 of 2009

Article 65 This clearly provides protection for the wife to be divorced by her husband, whose provide certainty and legal force then the divorce should be done in front of the court. If the divorce is done outside of the trial court's ex-wife then the consequences would be difficult to assert their rights as wives for example demanding a living on the waiting period, the division of joint property and others.

Article 66 paragraph (2) provide protection for the wife to be divorced husband. Protection here in terms of legal aid for the sake of ease the burden on the wife because the petition filed in court respondent's residence (wife).

Article 73 paragraph (1) protect his wife and helping his wife to file for divorce at the Religious Court in the place of domicile and not to the Religious Courts in the place of domicile of her husband.

- Compilation of Islamic Law

Article 149, Article 152, Article 158, Article 159 and Article 160 regulates the duty of the husband to his wife dropping divorce. The norms in the provisions of the Islamic Law Compilation materially or substantially enough to give protection to the wife who is divorced from her husband.

- Act No. 39 of 1999 on Human Rights

Norms contained in Article 5 and Article 17 generally provide equality of rights of citizens without any discrimination before the law. However, for vulnerable members of society are entitled to treatment and protection with regard to specificity, it is contained in Article 5 (1). Women in this case the wife could be categorized as a vulnerable group and deserve treatment and protection with these peculiarities.

- Law of the Republic of Indonesia Number 23 Of 2004 On the Elimination of Domestic Violence.

Act 23 of 2004 on the Elimination of Domestic Violence is more set in terms of the sentence, but there are certain articles that contain norms that can be used as a basis of law for judges in civil cases, especially concerning the protection of women as a result of neglect by her husband. It can be found in Article 5 (4) in whose the article contained a ban on domestic violence in the form of neglect. Furthermore, in Article 9 paragraph (1) states, in addition to the prohibition of neglect in the household is also no obligation to provide life, care and maintenance of the person in household. 
- Supreme Court Regulation No. 3 Of 2017 on Guidelines for Passing the Case of Women against the Law.

Supreme Court Regulation No. 3 Of 2017 providing guidance to judges when facing women in conflict with the law.

In Article 2, Article 4 letter b and c Article 6 authorizes the judge to provide special protection for women due to gender inequalities could lead to inequalities in law protection that have an impact on access to justice.

\subsection{Related Norm Analysis With Law Protection Against Wife Who Claims Fall Due His Husband Recompensation Reluctant Due To Divorce Pledge}

The norms that have been the author mentioned above is general in providing protection to women. Provisions governing the death verdict of divorce pledge clearly can be seen in Act No. 7 of 1989 On the Religious Courts as amended by Act No. 3 of 2006 and the second amendment by Act No. 50 of 2009 on Article 70 paragraph (6) asserts, if the husband within the period of 6 (six) months as the trial testimony divorce pledge, did not come before his own or did not send a representative despite've got a call lawfully or inappropriate then fall the setting power, and divorce can not be filed again the same reason.

Furthermore, in in the Compilation of Islamic Law Article 131, paragraph (4) states that "If the husband is not in divorce pledge within six (6) months since the decision of the Court of Religion on permit divorce pledge him have binding legal force the husband's right to divorce pledge fall and wedlock remains intact ".

Article 131, paragraph (4) Compilation of Islamic law is in line with the provisions contained in Article 70 paragraph (6) of Act No. 7 of 1989, but in the provision of Islamic Law Compilation there is a norm that states wholeness of the marriage bond between husband and wife.

With the death of the decision, then the marital bond between husband and wife is still intact as before. While it is possible marital relationship does not become good again, but instead put his wife in a position of uncertainty or dependent because formal marriage bond still bound to her husband but in real terms had not given his rights as a wife. If the wife wants to retain his rights back then he must file a new lawsuit and the examination will start from the beginning, whose would certainly make the wife's position more unfavorable, both in terms of time and cost. Because with the new filing examination will start again from the beginning, starting the registration process, the calling, the trial until the verdict.

Based on the above results, according to the authors studied the theory of law protection, norming protection to women especially to a wife who claim his recompensation fall due reluctant husband divorce pledge pronounce not enough to give law protection to the rights of the wife who should have been obtained from a previous verdict. The state should provide shelter to the rights of the wife are harmed by the husband by creating a new norm or change the norms that already exist by 
inserting a provision / chapter makes it easy for wives who will resubmit the claim his recompensation that have fallen due to the husband's reluctant oath of divorce either in terms of administration, the examination and remedies, as a form of safeguards that can be given by the court to the wife.

In terms of legal certainty, the existing norms in reality not provide law protection against the wife's position. When the husband does not carry out the vows, then their legal status is still valid to be the wife but the rights are not met by the husband. Therefore making the new norms that provide protection against the lawsuit wife husbands reluctant his recompensation fall due to divorce pledge needs to be done in order to create legal certainty.

\subsection{Forms of law Protection Against Wife Who Claims Fall Due His Husband Recompensation Reluctant Due To Divorce Pledge}

The presence of the state to protect women as mandated by the constitution is to protect the entire Indonesian nation is a duty that must be carried out by the government whose this obligation be a basic right for citizens without exception.

The court as one of the state institutions have an obligation to provide protection to women in particular who are victims of arbitrary actions of her husband.

Forms of state protection can be done by providing convenience to the wife who would file another lawsuit for divorce with cummulation of recompensation that have been asked before. Ease the wife could be given in the areas of administration, as well as events, in administration filed a lawsuit enough by enclosing a previous decision whose has had permanent legal force. In a lawsuit filed back then the principal claim, the subject and object of the lawsuit should be similar to the previous case by adding in posita reason why the case becomes void and the reason for filing the lawsuit back.

Efforts to provide law protection for the wife who claim his recompensation fall due to the arbitrariness of the husband as reluctant to drop the divorce pledges in the form of convenience in the procedural law applicable in the case investigation because the principal case had been filed and was decided by a judge with the judgment of positive and has never had the power permanent law (BHT), as well as to meet the legal principle of justice that is simple, fast and inexpensive.

Since the material or subject matter, subject and object were filed by wives or plaintiff is the same as the ruling filed by the husband and have gotten the decision is legally binding, the principle Similia Similibus should be applied by the judge. That is what will be decided by the judge to be the same as had been decided by the judges earlier.

The judge must also consider the legal principle of Res Judicate Pro Veritate Habetu, that the judge's ruling earlier must be true, because what is decided by the judge must first have gone through the evidence at trial, would constitute an event that actually happened according to the law, the previous decision has had permanent legal force and has never been revoked by a higher court level.

With the implementation of the principle of law Similia Similibus and Res Judicate Pro 
Veritate Habetu will bear the same verdict to the case ever decided by a judge that would keep their legal certainty.

\section{Closing}

\subsection{Conclusion}

- There are no norms both administrative and formal norms are enough to give special protection to wives whose husbands due to the fall his recompensation lawsuit reluctantly dropped the divorce pledge;

- Forms of law protection against lawsuits wife husbands reluctant his recompensation fall due to divorce pledge done by providing ease in administration as well as the procedural law for the wife who would resubmit its case in accordance with the legal principle is simple, fast and inexpensive.

\subsection{Suggestion}

- The Supreme Court needs to create a new norm either Circular or Perma whose specifically provides law protection to wives whose husbands lawsuit his recompensation fall due reluctant to implement the divorce pledge.

- Or change Perma No. 3 Of 2017 on Guidelines for Passing the Case of Women against the Law by adding a provision / chapter makes it easy for wives who will resubmit the claim his recompensation that have fallen due to the husband's reluctant oath of divorce both in terms of administration, the examination and remedies, as an effort to protection that can be given by the court to the wife.

\section{References}

[1] Johnny Ibrahim, Teori \& Metodologi Penelitian Hukum Normatif, Bayu Media Publishing, Malang, 2008.

[2] Soerjono Soekanto and Sri Mamuji, Penelitian Hukum Normatif Suatu Tinjauan Singkat, Raja Grafindo Persada, Jakarta, 2010.

[3] Constitution of the Republic of Indonesia 1945

[4] Act No. 1 Of 1974 On Marriage.

[5] Law of the Republic of Indonesia Number 7 of 1984 concerning the Ratification of Convention on the Elimination of All Forms of Discrimination against Women (Convention On The Elimination Of All Forms Of Discrimination Against Women).

[6] Act No. 7 of 1989 On the Religious Courts

[7] Act No. 39 of 1999 on Human Rights

[8] Law of the Republic of Indonesia Number 23 Of 2004 On the Elimination of Domestic Violence

[9] Act No. 3 of 2006 on the Amendment of Act No. 7 of 1989 On the Religious Courts. [10] Act No. 50 Of 2009 regarding the Second Amendment to Act No. 7 of 1989 On the Religious Courts. 
Jurnal Daulat Hukum: Volume 2 Issue 4, December 2019 : 543 - 550

[11] Government Peratuaran No. 9 of 1975 on the implementation of Act No. 1 of 1975 on Marriage

[12] Presidential Decree No. 1 of 1991 On the Compilation of Islamic Law

[13] Supreme Court Regulation No. 3 Of 2017 on Guidelines for Passing the Case of Women against the Law 